\title{
Penerapan Pembelajaran Tipe Co-op Co-op dan Team Games Tournament (TGT) pada siswa SMP dengan Materi Pelaku Ekonomi dan Perannya dalam Kegiatan Ekonomi
}

\author{
Made Saniyasa*1, Lulup Endah Tripalupi² \\ 1,2,3 Program Studi Pendidikan Ekonomi \\ Universitas Pendidikan Ganesha \\ Singaraja, Indonesia
}

e-mail: saniyasa03@gmail.com *1,tripalupilulup@gmail.com²

\begin{abstract}
Riwayat Artikel
Tanggal diajukan: 28 Mei 2021

Tanggal diterima : 23 November 2021

Tanggal dipublikasikan: 15 Desember 2021

Abstrak

Tujuan penelitian ini untuk menginvestigasi pencapaian siswa dengan menerapkan metode pembelajaran kolaboratif dan metode permainan kompetitif kelompok (Taem Games Tournament). Penelitian saat ini dilakukan pada kelas VIII SMP Negeri 8 Singaraja dengan melibatkan dua kelas. Teknik pengumpulan informasi dilakukan dengan menggunakan tes. Data analisis dilakukan dengan uji statistic dan hipotesis. Hasil paa penelitian ini menujukan adanya perbedaan yang signifikan terhadap hasil belajar siswa pada kelompok eksperimen dan kelompok control. Kelompok eksperimen dengan penerapan TGT menunjukan hasil yang relatif lebih baik dibandingkan dengan kelompok kontrol dengan penerapan pembelajaran tipe kolaboratif. Siswa dengan metode pembelajaran kooperatif meraig skor rata-rata 72,38 dan model pembelajaran TGT memperoleh skor ratarata 83,6 .
\end{abstract}

Pengutipan:

Saniyasa, M.

Tripalupi, L.E.,

Sujana, I.N.

(2021).Penerapan

pembelajaran

Tipe Co-op Co-op

dan Team Games

Tournament

(TGT) pada siswa

SMP dengan

Materi Pelaku

Ekonomi dan

Peranya dalam

Kegiatan

Ekonomi. Jurnal

Pendidikan

Ekonomi

Undiksha,13(2),

310-318

http://dx.doi.org/1

$0.23887 /$ jjpe.v13i2

.34804

Kata Kunci: Hasil Belajar Siswa; Model Pembelajaraan; Model Pembelajaran Kooperatif

\begin{abstract}
This research uses collective learning approaches and Team Games Tournaments to look at students' learning achievements. The study is now underway in SMP Negeri 8 Singaraja's grade VIII, including two classrooms. Tests are used to acquire data. Statistics and hypothesis tests are used to analyze the results. This study revealed that the experimental and control groups had substantial disparities in student learning outcomes. The experimental group that used TGT got significantly better results than the control group that used collaborative form learning. Students who used cooperative learning strategies received an average score of 72.38 , while those who used the TGT learning model received an average score of 83.6 .
\end{abstract}

Keywords: Learning Achievement; Learning Model; Learning Cooperative Model 


\section{PENDAHULUAN}

Pada pembelajaran hal yg paling utama merupakan proses, karena proses ini yang memastikan tujuan pembelajaran ingin tercapai. Akan terdapat perubahan prilaku jika proses pembelajaran tercapai. Perubahan perilaku tersebut meliputi aspek pengetahuan, sikap, dan keterampilan.

Setelah mengikuti pembelajaran maka terdapat keluaran terhadap hasil belajar yang diinginkan, dimiliki, atau dikuasai oleh. Pada proses pembelajaran hasil belajar memiliki peran penting. Hasil belajar digunakan untuk memahami batasan pemhaman siswa dalam materi tersebut.

Hasil IPS di SMP Negeri 8 Singaraja khususnya kelas VIII I dan VIII II masih sangat bervariasi. Dari peroleh informasi tentang data nilai hasil pengamatan awal setelah dilaksanakan ulangan harian pertama hanya mencapai rata-rata 56, masih relatif rendah dan terdapat nilai siswa yang tidak termasuk Kriteria Ketuntasan Minimum (KKM).

Menurut hasil pendalaman wawancara terhadap guru bidang IPS kelas VIII yang dilaksanakan oleh peneliti, selama proses pembelajaran dilakukan guru tersebut masih memanfaatkan metode ceramah. Akibatnya dalam proses pembelajaran siswa jadi malas dan tidak mau belajar sehinga membuat hasil belajarnya pun rendah. Selain itu, menimbulkan rasa kebosanan dan kejenuhan siswa untuk memperhatikan guru yang sedang melakukan kegiatan pembelajaran, sehingga hasil belajar bertentangan dengan harapan. Oleh karena itu, metode pembelajaran mempunyai peran khusus dalam hasil belajar disamping kemampuan peserta didik itu sendiri. Pemahaman materi dalam proses pembelajaran akan dipengaruhi oleh banyak aspek, pemilihan model pembelajaran yang tepat dapat mengubah dan menghasilkan keluaran yang sesuai serta maksimal.

Guna meningkatkan prestasi belajar siswa, maka teknik pembelajaran yang diterapkan hendaknya berbeda dan berfokus pada siswa. Metode pembelajaran kooperatif merupakan model pembelajaran yang berpusat pada keberhasilan siswa. Menurut Rusman (2012) pembelajaran kooperatif yaitu "sistem edukasi yang siswanya tebentuk dalam kelompok dalam jumlah empat ampai enam orang yng bersifat heterogen ". Saat pembelajaran ini berlangsung guru hanya sebagai jembatan penghubung agar siswa lebih mengerti tentang materi. Ada beberapa tipe dalam model pembelajaran kooperatif, peneliti akan menerapkan dua metode dalam penelitian ini yaitu Co-op Co-op dan (TGT) yang akan dilaksanakan pada dua kelas.

Menurut model pembelajaran kooperatif Thamimi dan Kusnoto (2017), teknik pembelajaran tipe kooperatif lebih unggul daripada model pembelajaran kooperatif tradisional. Oleh karena itu, setelah mengadopsi tipe kooperatif, dipastikan pencapaian belajar siswa menjadi lebih maksimal. Rosalina dkk., (2016) mengemukakan bahwa pembelajaran kooperatif siswa SMA bidang fisika mempunyai peran yang cukup besar dalam bidang koperasi psikologi dan psikomotor setelah pembelajaran kooperatif.

Model pembelajaran ini merupakan tipe TGT yang dimana model ini dengan mudah dapat digunakan tanpa memperhatikan pengecualian-pengecualian tertentu serta dalam model ini disisipkan permainan. Tarigan (dalam Yulianto, 2014) kestimewaan pembelajaran tipe TGT ialah melakukan turnamen yang dimana setiap anggota kelompok mewakili kelompoknya sehingga adanya kompetisi akademik pada saat pembelajaran. Pada penelitian yang dilakukan oleh Hikmah dkk., (2018) beliau mengatakan bahwa hasil belajar dan motivasi belajar sangat di pengaruhi oleh model pembelajaran yang digunakan. Dari hasil uji yang telah dilaksanakan diperoleh hasil tingkat signifikan lebih besar dari 0,05 (sig > 0,05), Kemudian thitung lebih besar dari $t_{\text {tabel }}$ yakni 9,634 > 2,000.

Berdasarkan pemaparan ini, peneliti memilih dua tipe model pembelajaran tersebut karena kedua tipe model pembelajaran tersebut memfokuskan pada aktivitas peserta didik. Akan tetapi, terdapat sebuah perbedaan yaitu pada model tipe satu pada model ini siswa diharapkan mampu menyampaikan materi yang sudah ditemukan sebelumnya pada kelompok lain. Sedangkan, model pembelajaran tipe TGT 
para peserta didik berkompetisi agar kelompoknya menjadi juara. Dari uraian tersebut kedua model tersebut sama-sama mempengaruhi pencapaian siswa dalam pembelajaran namun terdapat perbedaan hasil dengan jumlah yang berbeda.

Oleh karena itu, penting untuk melakukan penelitian terkait dengan dua tipe pembelajaran tersebut pada kelompok siswa yang berbeda. Sehingga, penelitian ini dilakukan untuk memecahkan permasalahan yang telah disusun sebelumnya masalah-masalah yang sudah di rumuskan sebelumnya yaitu menginvestigasi perbedaan hasil pembelajaran pada siswa kelas VIII SMP Negeri 8 Singaraja dengan materi pelaku ekonomi dan perannya dalam kegiatan ekonomi.

Teknik pembelajaran memiliki peran yang penting pada kegiatan pembelajaran di kelas. Menurut Lefudin (2017) model pembelajaran adalah "sebuah konsep mengajarkan materi dengan usaha mencapai tujuan tertentu". Oleh karena itu, model pembelajaran dipakai sebagai penuntun dalam memenuhi kegiatan pembelajaran. Menurut Fathurrohman (2015) model pembelajaran ialah "suatu kerangka yang menjelaskan secara sistematik dalam menuangkan pengalaman belajar dan pembelajaran oleh guru alam menjalankan kegiatan belajar mengajar". Ada beberapa jenis model pembelajaranan diantaranya pembelajaran langsung, pembelajaran kooperatif (cooperative learning), atau model pembelajar berbasis masalah, Menurut Nurdyansyah and Fahyuni (2016) mengatakan bahwa dalam proses pembelajaran peserta didik dalam belajar bekerjasama dalam sebuah kelompok kecil yang heterogen sehingga mereka dapat belajar dengan lebih aktif.

Model pembelajaran kooperatif tipe Co-op Co-op merupakan beberapa usaha yang diupayakan oleh seorang pendidik dalam menaikkan mutu proses pembelajaran. Dalam model ini terdapat langkah-langkah yang mengarahkan keaktifan siswa di pelajaran agar selalu siap tampil dihadapan temannya. Dalam model ini pembelajaran kooperatif terdiri dalam kelompok kecil yang bertumpu dalam mempelajari materi yang diberikan, model ini disebut juga sebuah bentuk group investigation yang cukup familiar (Aliati dkk., 2017). Menurut Slavin (2015) model pembelajaran kooperatif tipe ini ialah group investigation yang cukup dikenal. Tipe ini digunakan untuk mempelajari sebuah materi di kelas dengan grup satu dengan grup yang lainnya (seperti namanya). Tipe ini menugaskan peserta didik supaya berkerjasama satu dengan peserta didik lainnya. Pembelajaran jenis ini mengajarkan siswa untuk berbagi informasi dan pemahaman dengan yang lain.

Model ini cocok digunakan karena mempunyai kelebihan yaitu 1) mengajarkan peserta didik untuk mencari materi dari sumber lain serta belajar pada peserta didik lainnya supaya lebih percaya lagi dalam kemampuannya sendiri 2) memotivasi peserta didik supaya mengutarakan pendapatnya secara verbal dan membandingkan terhadap pendapat peserta didik lainnya. 3) mengajarkan menghormati dan menerima pendapat yang berbeda dari temannya baik menghormati siswa yang pindai serta siswa yang kurang pandai 4) membantu siswa dengan kemampuan kurang agar bias tetap mengikuti proses pembelajaran. 5) menumbuhkan cara berfikir kreatif dari seorang siswa. 6) membuat peserta didik aktif membuat dan menyampaikan ide mereka. 7) peserta didik memiliki pengalaman yang kaya pada proses menemukan dan menerima persetujuan dari peserta didik lainnya terhadap ideidemereka. Dalam penerapan model pembelajaran ini pengajar hanya menjadi sebagai motivator, perantara dan fasilitator.

$$
\text { Model pembelajaran mudah }
$$

diterapkan karena setiap model pembelajaran memiliki langkah - langkah dalam prosesnya. Menurut (Slavin, 2015) ada Sembilan langkah diantaranya, proses belajar terpusat pada siswa, memilih tim belajar dan membentuknya, memilih topik untuk setiap tim, membagikan topik kecil, merencanakan topik kecil, penyampaian topik kecil, persentasi tim dan yang terakhir evaluasi untuk setiap tim.

$$
\text { Pembelajaran jenis TGT }
$$
menggunakan permainan yang mudah diterapkan siswa berperan aktif dalam menjadi tutor sebaya untuk teman- 
temannya tanpa mengesampingkan kemampuan dari setiap siswa (Shoimin, 2014). Melalui TGT siswa akan ditempatkan dalam tim heterogen, baik dalam jenis kelamin, prestasi akademik maupun ras, dengan jumlah siswa dalam setiap kelompoknya berjumlah tiga sampai empat siswa.

Keunggulan pembelajaran tipe Teams Games Tournaments (TGT) yaitu pada saat proses pembelajaran akan adanya turnamen akademik. Untuk melakukan turnamen setiap kelompok akan ada perwakilan yaitu anggota kelompok tersebut. Menurut Saco dalam Rusman (2012) ini siswa ditugaskan untuk memperoleh skor masing-masing untuk setiap kelompoknya. Guru akan membuat pertanyaan-pertanyaan dalam bentuk kuis untuk permainan yang akan dilakukan. Pertanyaan tidak jarang dapat diselingi yang berkaitan dengan kelompok (identitas kelompok mereka). Dari uraian diatas bisa ditarik kesimpulan bahwa model pembelajaran tipe TGT ialah pola belajar dengan menerapkan permainan/turnamen kelompok yang dimana anggota kelompoknya dibagi atas dasar kemampuan, untuk memperoleh nilai yang ditargetkan kemudian nilai menjadi skor keunggulan kelompoknya.

Menurut Shoimin (2014) berikut langkah atau sintak pembelajaran TGT terdiri atas 5 (lima) yaitu, penyampaian materi di awal kelas, diskusi yang dilaksanakan dalam kelompok, inti dari langkah ini yaitu permainan, selanjutnya pertarungan atau kompetisi dari setiap kelompok, tahap akhir yaitu apresiasi kepada kelompok karena telah menyelsaikan pembelajaran dengan sangat baik.

Secara sederhana, hasil belajar siswa merupakan capaian yang mampu dicapai pembelajaran. Hasil belajar merupakan pencapaian yang muncul setelah menyelesaikan tanggung jawab melalui hasil tes di akhir pembelajaran (Sinar, 2018; Sudjana, 2019). Selain itu, hasil belajar dapat didefinisikan sebagai suatu tolak ukur pembelajaran yang akan mempengaruhi keberhasilan suatu pendididikan (Suprayektif dalam Naimah, 2019).
Benyamin Bloom (N. Sudjana, 2019) membagi aspek pembelajaran menjadi kognitif atau pengetahuan, afektif atau sikap, dan psikomotorik atau keterampilan. Aspek kognitif atau pengetahuan berkaitan dengan pengetahuan dan kemampuan berpikir siswa pendidikan. Kedua, aspek sikap yang berkaitan dengan diri siswa dalam mengontrol emosi, minat serta perasaan. Terakhir yaitu aspek keterampilan yang berhubungan dengan aktifitas yang dilakukan oleh siswa. Ketiga aspek tersebut mendapat perhatian dalam proses pembelajaran. Namun, aspek pengetahuan memiliki peran lebih dalam kaitannya dengan pencapaian siswa.

Berdasarkan uraian pada latar belakang, penulis merumuskan masalah yang akan dibahas dalam penelitian ini sebagai berikut. (1) Bagaimana hasil belajar siswa yang diajar dengan model pembelajaran kooperatif tipe Co-op Co-op? (2) Bagaimana hasil belajar siswa yang diajar dengan model pembelajaran pembelajaran kooperatif tipe Team Games Tournamen (TGT)? (3) Apakah terdapat perbedaan hasil belajar siswa yang diajar menggunakan model pembelajaran kooperatif tipe Co-op Co-op dengan tipe Team Games Tournament (TGT) pada kelas VIII SMP Negeri 8 Singaraja?

Adapun tujuan dalam penelitian ini yakni untuk mengetahui: (1) Hasil belajar siswa yang diajar dengan model pembelajaran kooperatif tipe Co-op Co-op. (2) Hasil belajar siswa yang diajar dengan model pembelajaran kooperatif tipe Team Games Tournamen (TGT). (3) Apakah terdapat perbedaan hasil belajar siswa yang diajar dengan model pembelajaran kooperatif tipe Co-op Co-op dan tipe Team Games Tournamen (TGT) pada kelas VIII SMP Negeri 8 Singaraja.

\section{METODE}

Penelitian saat ini merupakan sebuah penelitian eksperimen klasik (Classical experimental design). Desain penelitian Classical experimental design dipilih karena peneliti memiliki 2 kelompok subjek. Kelompok tersebut sama-sama mendapat perlakuan, tetapi keduanya mendapat perlakuan yang berbeda. Subjek yang digunakan yaitu siswa kelas 8.1 
sebagai kelas model tipe 1 dan kelas 8.2 sebagai model tipe 2 di SMP Negeri 8 Singaraja. Sedangkan objek studi ini adalah hasil belajar siswa kelas VIII SMP Negeri 8 Singaraja setelah dilakukan diterapkan pembelajaran dengan teknik yang sudah ditetapkan.

Teknik pengumpulan informasi dilakukan dengan memanfaatkan tes sebagai instrumen penelitian. Teknik pengukuran yang digunakan berupa tes lisan dan tertulis dengan beragam bentuk dan skala pengukurnya. Tes diberikan kepada responden untuk selanjutnya dianalisis. Alat pengukur yang digunakan yaitu tes objektif pilihan ganda pada mata pelajaran IPS dengan materi pelaku ekonomi dan perannya dalam kegiatan ekonomi. "Validitas berkaitan dengan kekuratan ala penilaian dengan konsep yang akan dinilai dengan demikian dapat menilai yang seharusnya dinilai" ( $N$. Sudjana, 2019). Menghitung validitas pada penelitian ini menggunakan rumus sebagai berikut:

$r_{p b i}=\frac{\mathrm{M}_{p}-\mathrm{M}_{q}}{S_{t}} \sqrt{p q}$

$r_{p b i}=$ koefisien korelasi point biserial

$\mathrm{Mp}=$ jumlah responden yang menjawab benar

$\mathrm{Mq}=$ jumlah responden yang menjawab salah

St $=$ standar deviasi untuk semua item

$\mathrm{P}=$ proporsi responden yang menjawab benar

$\mathrm{Q}=$ proporsi responden yang menjawab salah

Realibilitas atau penilaian adalah kepastian dalam menilai yang seharusnya diniai. Menurut (Nana Sudjana, 2019) mengemukakan bahwa "tes hasil belajar dikatakan ajeg apabila hasil dari waktu ke waktu tetap sama dan konsisten". Untuk menghitung reliabilitas soal tes maka rumus yg digunakan KR (Kuder Richardson). Rumus dapat dilihat pada formula dibawah ini.

$$
r_{X X}=\frac{k \sigma x^{2}-X(K-\bar{X}}{\sigma x^{2}(K-1)}
$$

$r_{x x}=$ reliabilitas tes secara keseluruhan

$\mathrm{K}=$ jumlah butir soal dalam tes

$\sigma x^{2}=$ variasi skor

$\overline{\mathrm{X}}=$ skor rata-rata (mean score)

Untuk menguji penelitian ini digunakan uji t dengan menggunaan dua sampel. Dalam proses pengolahan data peneliti menggunakan windows SPSS 16.0 untuk menghitung analisis data.

Rancangan pengujian hipotesis dapat dilihat dibawah ini: a) HO: Tidak ada perbandingan yang signifikan terhadap pencapaian siswa kelas VII SMP Negeri 8 Singaraja dengan menerapkan teknik pembelajaran kolaboratif dan teknik Team Game Tournament (TGT). b) Ha: Terdapat perbedaan hasil belajar siswa kelas VIII SMP Negeri 8 Singaraja yang signifikan dengan teknik pembelajaran kooperatif dan Team Game Tournament (TGT).

\section{HASIL DAN PEMBAHASAN}

a) Hasil Belajar Siswa dengan Menerapkan Model Pembelajaran Co-op Co-op

Berdasarkan penelitian pada topik penelitian sosial di kelas VIII.1 SMPN 8 Singaraja, penulis menggunakan model pembelajaran tipe kooperatif untuk memperoleh data dari tes yang telah disebar dalam bentuk pencapaian siswa. Hasil tersebut ditunjukan oleh tabel dibawah ini. 
Tabel 1

Hasil Belajar Siswa Menggunakan Model Pembelajaran Kooperatif Tipe Co-op Co-op

\begin{tabular}{|c|c|c|c|c|}
\hline & No & $\begin{array}{c}\text { Kelas } \\
\text { Interval }\end{array}$ & Frekuensi & $\begin{array}{c}\text { Presentase } \\
\text { Komulatif } \\
(\%)\end{array}$ \\
\hline 1 & & $60-66$ & 7 & 21,9 \\
\hline 2 & & $67-73$ & 16 & 50,0 \\
\hline 3 & & $74-80$ & 5 & 15,6 \\
\hline 4 & & $81-87$ & 0 & 0 \\
\hline 5 & & $88-94$ & 1 & 3,1 \\
\hline 6 & & $95-101$ & 3 & 9,4 \\
\hline & Jumlah & & 32 & 100 \\
\hline
\end{tabular}

Sumber: (data diolah peneliti)

Dapat dilihat pada table 1 bahwa perolehan nilai posttest siswa kelas VIII.1 pada interval 60-66 frekuensinya sebesar 7 dengan presentasi $21,9 \%$, pada interval 67 73 frekuensinya sebesar 16 dengan presentasi $50,0 \%$, pada interval $74-80$ frekuensinya sebesar 5 dengan presentasi $15,6 \%$, pada interval $81-87$ frekuensinya sebesar 0 dengan presentasi $0 \%$, pada interval 88-94 frekuensinya sebesar 1 dengan presentasi sebesar $3,1 \%$, dan pada interval 95-101 frekuensinya sebesar 3 dengan presentasi 9,4\%. Diperoleh hasil 72,38 dengan hasil diatas standar sebanyak 25 orang, sedangkan siswa lainnya memperoleh hasil dibawah standar yang ditentukan.

b) Hasil Belajar Siswa dengan Menerapkan Model Pembelajaran TGT

Berdasarkan penelitian pada topik penelitian sosial pada VIII.2 SMPN 8 Singaraja, penulis menggunakan teknik pembelajaran tipe Team Game Tournament (TGT) untuk mengumpulkan data dari tes instrumen melalui hasil belajar. Data tersebut ditunjukkan pada tabel dibawah ini:

Tabel 2

Hasil Belajar Siswa Menggunakan Model Pembelajaran Kooperatif Tipe Team Games Tournamen (TGT)

\begin{tabular}{cccc}
\hline No & $\begin{array}{c}\text { Kelas } \\
\text { Interval }\end{array}$ & Frekuensi & $\begin{array}{c}\text { Presentase } \\
\text { Komulatif } \\
(\%)\end{array}$ \\
\hline 1 & $72-76$ & 8 & 25 \\
2 & $77-81$ & 9 & 28,1 \\
3 & $82-86$ & 3 & 9,4 \\
4 & $87-91$ & 4 & 12,5 \\
5 & $92-96$ & 6 & 18,8 \\
6 & $97-101$ & 2 & 6,3 \\
& & 32 & 100 \\
\hline \multicolumn{4}{c}{ Jumlah } \\
Sumber: (data diolah peneliti)
\end{tabular}

Tabel 4.2 menunjukan perolehan nilai post test peserta didik kelas VIII.2 pada interval $72-76$ frekuensinya sebesar 8 dengan presentasi $25 \%$, pada interval 77 -
81 frekuensinya sebesar 9 dengan presentasi $28,1 \%$, pada interval $82-86$ frekuensinya sebesar 3 dengan presentasi $9,4 \%$, pada interval $87-91$ frekuensinya 
p-ISSN : 2599-1418

e-ISSN : 2599-1426

sebesar 4 dengan presentasi $12,5 \%$, pada interval $92-96$ frekuensinya sebesar 6 dengan presentasi sebesar 18,8\%, dan pada interval 97-101 frekuensinya sebesar 2 dengan presentasi 6,3\%. Dengan demikian, terdapat 32 siswa yang nilainya melebihi KKM. Pada hasil uji yang sudah dilakukan, mendapat hasil belajar siswa yang sangat baik, hal ini berarti model TGT dapat meningkat pemahaman siswa dalam belajar di kelas.

c) Perbedaan Hasil Pembelajaran dengan Model Pembelajaran Co-op Co-op dan TGT

Hasil uji-independen sample t-test menunjukan bahwa pecapaian siswa siswa yang berbeda dengan menerapkan kedua model pembelajaran tersebut. Berdasarkan uji hipotesis penelitian, diusulkan metode penggunaan independent sample t test.

Hasil akan ditolak jika nilai signifikansi $<0,05$. Hal ini berarti terdapat beda antara hasil tes antara kedua kelompok tersebut. Sedangkan, HO diterima jika nilai signifikansi> 0,05. Dapat dikatakan bahwa tidak ada perbedaan yang signifikan terhadap hasil post-test. Berdasarkan rangkuman hasil pada uji SPSS, hasil analisis menyatakan bahwa nilai Sig <e 0,005 yaitu $0,0 \mathrm{e} 00<0,005$ seheingga $\mathrm{He}_{0}$ diterima, Hal ini berarti terdapat perbedaan yang signifikan antara kelompok siswa dengan teknik TGT dan kooperatif pada mata pelajaran IPS kategori VIII SMPN 8 Singaraja. Pada tahun ajaran 2020/2021. Selanjutnya, perbandingan hasil belajar menggunakan metode TGT dan co-op coop dapat dilihat pada tabel dibawah ini.

Berdasarkan hasil analisis uji SPSS pada kolom Mean menunjukkan perbandingan ketuntasan hasil belajar (Post-Test) ekonomi materi konsep ilmu ekonomi, masalah ekonomi dan sistem ekonomi kelompok eksperimen yang memakai metode Co-op Co-op memperoleh nilai 72,44 dan model pembelajaran TGT memperoleh nilai sebesar 83,69.

a) Hasil Belajar Siswa dengan Penerapan Model Pembelajaran Kooperatif Tipe Co-Op Co-Op
JurnalPendidikanEkonomiUndiksha

Vol.XXNo.X (2020)

Penerapan model pembelajaran di SMP Negeri 8 masih belum maksimal untuk meraih prestasi belajar perserta didik. Standar yang mampu dicapai siswa yaitu pada nilai rata-rata 72,38 . Oleh karena itu, teknik pembelajaran dengan fokus hasil belajar siswa sangat dibutuhkan. Proses pembelajaran yang menyenangkan dapat menstimulasi motivasi siswa untuk menerima materi pembelajaran.

b) Hasil Belajar Siswa dengan Penerapan Model Pembelajaran Kooperatif Tipe TGT

Sedangkan, penerapan model pembelajaran TGT siswa menunjukan perlikau yang lebih aktif dalam pembelajaran. Hasil yang ditunjukan sebesar 83,63 diatas rata-rata. Hal tersebut membuktikan bahwa siswa mampu menguasai pembelajaran yang diberikan. Hasil penelitian saat ini menunjukan hasil yang serupa dengan penelitian sebelumnya, dimana hasil belajar siswa meningkat saat diterapkan teknik TGT (Wisnu dalam Yulianto, 2014).

c) Perbedaan Hasil Pembelajaran dengan Model Pembelajaran Co-op Co-op dan TGT

Uji statistik menunjukan bahwa terdapat perbandingan yang relevan antara hasil belajar kelompok kontrol dan eksperimen. Hasil uji hipotesis menunjukan pencapaian siswa pada mata pelajaran IPS dengan perlakuan TGT lebih maksimum dari pada kelas dengan perlakuan pembelajaran $\mathrm{Co}$ op Co-op. Hasil yang lebih maksimal ditunjukan oleh kelas eksperimen dengan penerapan teknil pembelajaran TGT.

Penerapan Team Games Tournament (TGT) pada saat peneliti melakukan penelitian terlihat siswa lebih aktif bertanya maupun lebih aktif menjawab pada saat diskusi antar kelas dan keaktifan tersebut bersifat merata, tidak ada kesenjangan bagi siswa yang pintar maupun siswa yang kurang cerdas. Penerapan model belajar co-op co-op membuat siswa yaeng kemampuannya kurang menjadi pasif dan cenderung diam dibandingkan dengan siswa lainnya. Siswa dengan kemampuan lebih maksimal dari lainnya akan lebih aktif dan dominan. Sedangkan siswa yang 
kemampuannya kurang mereka merasa tidak bisa menjawab sama sekali. Hal itu dikarenakan para siswa tersebut tidak terbiasa menyelesaikan masalah yang nyata, mereka lebih terbiasa menyelesaikan masalah setelah ada contoh soal dari guru sehingga mereka kesulitan menangkap inti dari pembelajaran tersebut. Proses diskusi dan tanya jawab terjadi hanya antar siswa yang pintar, tidak semua siswa mengeti inti dan konsep dari pembelajaran yang diberikan.

Pemahaman peserta didik setelah proses pembelajaran Team Games Tournament (TGT) lebih merata, taka da tumpeng tindih antar siswa satu dengan, terlihat hampir sebagian besar siswa mudah dalam memahami konsep pembelajaran. Peta konsep yang disajikan peneliti adalah stimulus yang mudah diterima dan di respon oleh siswa. Hal tersebut dilihat dari mudahnya siswa menjawab soal yang disiapkan oleh peneliti dan mengingat ide-ide apa saja jika ditanya ulang, siswa dapat dengan dengan mudah mengerti dari inti materi pembelajaran yang diberikan oleh peneliti secara terseruktur. Sependapat dengan penelitian yang dilakukan oleh wahyuningsih (Rahayu, 2015) dalam pembelajaran dengan metode kooperatif siswa jadi lebih aktif dengan berinteraksi dengan teman-temannya. Pernyataan lain yang dikemukakan oleh Daryanto; Mulyo Rahardjo (2012) mengemukakan bahwa pembelajaran kolaboratif bermanfaat untuk meningkatkan prestasi belajar siswa secara maksimal dikarenakan setiap siswa mampu bertukar pikiran dengan teman-temannya.

Pada saat penerapan model pembelajaran TGT siswa juga menghasilkan catatan yang lebih rapi karna mereka dengan mudah menemukan poinpoin dari setiap materi yang sudah diberikan. Sehingga hal tersebut akan mempermudah mereka untuk mempelajarinya dikemudian hari untuk menghadapi tes ataupun soal ulangan. Maka dari hal tersebut model pembelajaran TGT sangat cocok digunakan pada SMP Negeri 8 Singaraja. Demikian pula prestasi siswa dengan teknik belajar co-op co-op, siswa mampu meningkatkan hasil belajar dengan tanggung jawab yang telah diberikan.

\section{SIMPULAN DAN SARAN}

Dapat disimpulkan bahwa:

Metode dengan tipe kooperatif yang diterapkan pada siswa masih belum maksimal. Hal tersebut didukung dengan rata-rata skor yang menunjukan sebesar 72.38. Sedangkan, pada kelompok eksperimen dengan penerapan TGT memperoleh hasil sebesar nilai rata -rata 83,63.Terdapat perbedaan hasil yang signifikan pada mata pelajaran IPS pada kelompok eksperimen kelompok kontrol di SMP Negeri 8 Singaraja berdasarkan uji yang telah dilakukan.

Terdapat beberapa saran yang diberikan terkait dengan peneltian saat ini, diantaranya:

Pengajar seharusnya mengusahakan memakai model atau metode pembelajaran yang bervariasi pada proses pembelajaran.

Siswa diharapkan nantinya mampu mengaplikasikan teori yang diperolehnya pada aktivitas sehari-hari, tidak hanya sekadar menguasai teorinya saja.

Penelitian ini bisa digunaan oleh guru sebagai acuan memperbaiki proses pembelajaran guna meningkatkan pencapaian belajar SMP Negeri 8 Singaraja dengan teknik pembelajaran tipe kooperatif dan TGT.

\section{DAFTAR PUSTAKA}

Aliati, Y. I. B. S. F. (2017). Perbandingan Pengaruh Model Co-op Co-op Dengan Integrated Reading And Composition Terhadap Hasil Belajar Peserta Didik Pada Mata Pelajaran Ekonomi Di SMA Negeri 1 Pagaralan. Jurnal Profit, Vol 4 No 1.

Daryanto; Mulyo Rahardjo. (2012). Model Pembelajaran Inovatif. Gava Media.

Fathurrohman, M. (2015). Belajar \& Pembelajaran Inovatif Alternatif Desain Pembelajaran yang Menyenangkan. Ar-Ruzz Media.

Hikmah, M. Y. A. R. H. (2018). Penerapan Model Pembelajaran Team Games Tournament (TGT) Terhadap Motivasi 
p-ISSN : 2599-1418

e-ISSN : 2599-1426

dan Hasil Belajar Peserta Didik Pada Materi Dunia Hewan Kelas X di SMA Unggul Negeri 8 Palembang. Jurnal Pembelajaran Biologi, Vol 5 No 1.

Lefudin. (2017). Belajar \& Pembelajaran Dilengkapi dengan Model Pembelajaran, Strategi Pembelajaran, Pendekatan Pembelajaran dan Metode Pembelajaran. Deepbulish.

Nurdyansyah \& Eni Fariyatul Fahyuni. (2016). Inovasi Model Pembelajaran Sesuai Kurikulum 2013. Deepbulish.

Rahayu, W. (2015). Model Pembelajaran Komeks: Bermuatan nilai-nilai Pendidikan Karakter Aspek Membaca Intensif di SD. Deepublish.

Rosalina, S. M., Indrawati, \& Mahardika, I. K. (2016). Model pembelajaran kooperatif tipe co-op dalam pembelajaran fisika siswa SMA. Jurnal Pembelajaran Fisika, 5(2), 162-169.

Rusman. (2012). Model-Model Pembelajaran Mengembangkan Profesionalisme Guru. PT. Rajagrafindo Persada.

Shoimin, A. (2014). 68 Model Pembelajaran Inovatif dalam Kurikulum 2013. Ar-
JurnalPendidikanEkonomiUndiksha

Vol.XXNo.X (2020)

Ruzz Media.

Sinar. (2018). Metode Active Learning Upaya Peningkatan Keaktifan dan Hasil Belajar Siswa. CV. Budi Utama.

Slavin, R. E. (2015). Cooperative Learning Teori, Riset dan Praktik. Penerbit Nusa Media.

Sudjana, N. (2019). Penelitian hasil proses belajar mengajar. PT. Remaja Rosdakarya.

Sudjana, Nana. (2019). Penelitian Hasil Proses Belajar Mengajar. PT. Remaja Rosdakarya.

Thamimi, M., \& Kusnoto, Y. (2017). Penerapan model pembelajaran kooperatif tipe co-op co-op terhadap kemampuan mengidentifikasi unsur intrinsik cerpen siswa kelas $X$. Edukasi: Jurnal Pendidikan, 15(2), 253-260.

Yulianto, W. D. K. S. E. B. (2014). Model Pembelajaran Teams Games Tournament Untuk Meningkatkan Hasil Belajar Siswa SMK. Journal of Mechanical Engineering Education, Vol 1 No 2. 